\title{
Occupational safety needs into construction formwork market. Perception of stakeholders
}

\author{
Necesidades de seguridad laboral en el mercado de encofrados en construcción. Percepción de \\ los grupos de interés
}

Antonio Lopez-Arquillos (Main and Corresponding autor)

Escuela de Ingenierías Industriales, Universidad de Málaga

C/ Dr. Ortiz Ramos s/n (Teatinos), 29071, Málaga (Spain)

alopezarquillos@uma.es

\section{María del Carmen Pardo-Ferreira}

Escuela de Ingenierías Industriales, Universidad de Málaga

C/ Dr. Ortiz Ramos s/n (Teatinos), 29071, Málaga (Spain)

carmenpf@uma.es

\section{Alistair Gibb}

School of Civil \& Building Engineering, Loughborough University

Loughborough LE11 3TU (United Kingdom)

A.G.Gibb@lboro.ac.uk

\section{Juan Carlos Rubio-Romero}

Escuela de Ingenierías Industriales, Universidad de Málaga

C/ Dr. Ortiz Ramos s/n (Teatinos), 29071, Málaga (Spain)

juro@uma.es

Manuscript Code: 1984

Date of Acceptance/Reception: 30.03.2019/27.09.2017

DOI: $10.7764 /$ RDLC.18.1.16

\begin{abstract}
This manuscript presents a comparative research about the perception of safety needs in the design and use of formworks. Needs were evaluated compiling opinions from different stakeholders in the construction sector in Spain and United Kingdom. Research methodology involved different phases: definition of the territorial and population context, research tool design, data collection and data analysis and findings. Thus, an ad-hoc questionnaire was designed and distributed to project designers, construction companies and manufacturing formwork companies, in order to identify needs in the design phase, construction phase and legal issues. The findings in both countries showed a high agreement in items related with productivity and final cost during the design phase of the formwork/falsework. Suppliers and customers showed different perception about the training services, especially in Spain. This study has allowed the identification of the sector's needs through the opinion of the main participants in the formwork trade. This should be a good basis for the development of measures that improve health and safety levels in formwork activities.
\end{abstract}

Keywords: Construction, occupational safety, prevention, formwork, stakeholders

Resumen

Este trabajo presenta una investigación comparativa sobre la percepción de las necesidades de seguridad en el diseño y uso de encofrados. Dichas necesidades fueron evaluadas recabando opiniones de diferentes grupos de interés en el sector de la construcción en España y Reino Unido. La metodología de investigación implicó diferentes fases: definición del contexto, diseño de la herramienta de investigación, recolección de datos y análisis y hallazgos. Así, se diseñó un cuestionario ad-hoc y se distribuyó a diseñadores de proyectos, empresas de construcción y empresas de fabricación de encofrados, para identificar las necesidades en fase de diseño, fase de construcción y problemas legales. Los hallazgos en ambos países mostraron un alto acuerdo en los items relacionados con la productividad y el coste final durante la fase de diseño del encofrado. Proveedores y clientes mostraron una percepción diferente sobre los servicios de formación, especialmente en España. Este estudio ha permitido identificar las necesidades del sector a través de la opinión de los principales participantes en el mercado de encofrados. Esta debería ser una buena base para el desarrollo de medidas que mejoren los niveles de salud y seguridad en las actividades de encofrado.

Construction accidents continue to be an international cause of concern. This concern is justified because at least 60.000 people die and many hundreds of thousands more suffer injuries and ill-health every year according to the International Labour Organization (ILO, 2013). Statistics from the United States (BLS, 2011) recorded 751 deaths on construction sites in 2010 while in the original 15 EU Member States about 1,300 construction workers die every year (OHSA, 2004). 
Many researches on construction occupational health and safety are focused on topics such as the impact of the different variables on the severity of the accidents (Chau et al., 2004; López-Arquillos, Rubio-Romero, \& Gibb, 2012; Salminen, 2004; Sawacha, Naoum, \& Fong, 1999) contributing factors in construction accidents (Haslam et al., 2005) or the safety risk assessment in construction activities (Hallowell \& Gambatese, 2009). Researches focused on the concept of design for construction safety also known as Prevention through Design concept (PtD) are especially relevant when accidents in civil construction are studied. Authors like Behm (2005), and Gambatese et al. (2008) studied the influence of the project design in the construction worker safety. In their studies they analyzed links between construction fatalities and the design for construction safety concept. Their results showed that $42 \%$ of fatalities reviewed were linked to the cited concept.

Different influence groups are present on the health and safety of construction site employees since the design of the project begins. Influence of contractors has been studied by authors like Wang et al. (2006), Saurin et al. (2008) and Fadier \& De la Garza (2006). In others similar researches, influence of the designers or structural engineers has been analyzed by Gambatese \& Hinze (1999), Behm (2005), Frijters \& Swuste (2008) and Gambatese et al. (2008). In contrast of previous influence groups, literature focused on the influence of the formwork manufacturing companies on the occupational health and safety of construction site has not been found. However, they are present in majority of civil construction works. On the other hand, among construction tasks, formwork activities are frequently associated with high rates of accidents and injuries. According to Huang \& Hinze (2003), 5.83\% of falls were attributed to the construction of formwork or to the construction of temporary structures, and around $21 \%$ of all accidents involved wood framing or formwork construction.

In addition to all of that, comparison between countries, have been demonstrated in the literature as an effective practice in research about occupational safety in construction issues (Morillas, Rubio-Romero, \& Fuertes, 2013; Recarte Suazo \& Jaselskis, 1993; Spangenberg et al., 2003; Zou \& Zhang, 2009).

This study aims to identify the actual safety needs and performance of the Prevention through Design in the use and designs of formworks in the civil construction sector through the opinions from project designers, construction companies or contractors, and formwork/falsework manufacturing companies from two different countries: a Hispanic country as Spain and an Anglo-Saxon country as United Kingdom.

Methodology

The performance feedback literature (Borman, 1997; Brutus, Fleenor, \& London, 1998; London \& Wohlers, 1991) recommends that in order to a better understanding and a more accurate of the occupational safety levels, feedback should be sought from multiple sources. It is assumed that multi-source feedback provides unique information from different perspectives, adding incremental validity to performance assessment (Borman, 1997). In this research, it was expected that feedback from the different groups of interest from different countries would be different and each group would provide a unique perspective to improve the change needed.

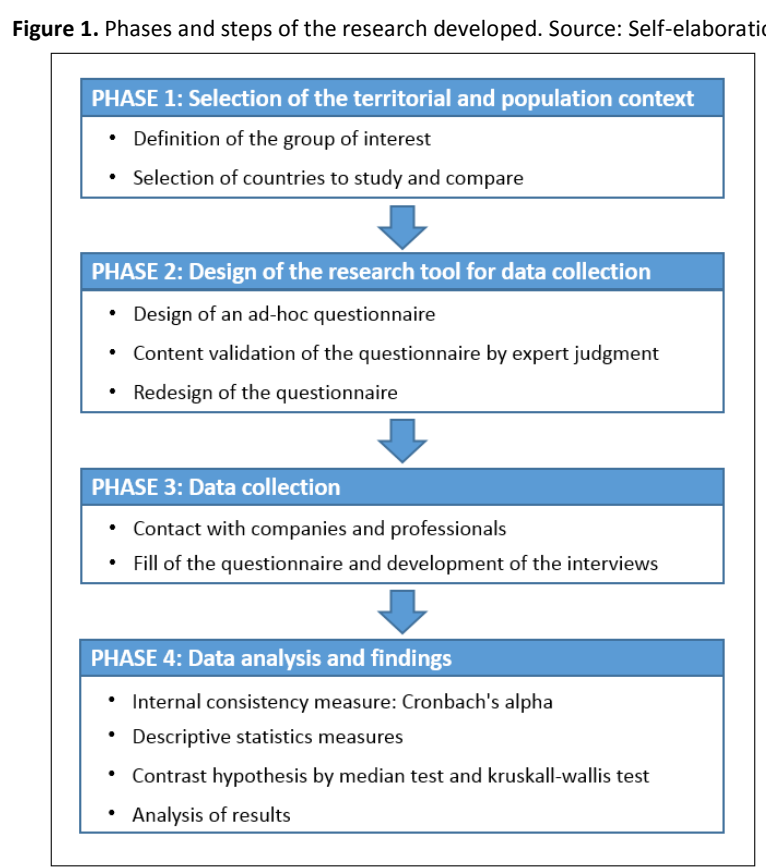


Figure 1 shows the different phases conducted during the development of this study. In this way, the first phase focused on the selection of the territorial and population context to be investigated. The first step was to identify the different influence groups in the issue of formwork in civil construction. Each group was identified according to the main steps in the product life: a) Design, b) Manufacturing c) Commercialization and d) Using. Groups identified and considered were described in Table 1.

\begin{tabular}{|c|c|c|}
\hline Rol in the market & $\begin{array}{l}\text { Professional } \\
\text { group }\end{array}$ & Expert definition \\
\hline $\begin{array}{l}\text { Who designs the } \\
\text { formwork/falsework } \\
\text { manufactures and trade } \\
\text { it? }\end{array}$ & $\begin{array}{l}\text { Formwork } \\
\text { manufacturing } \\
\text { company }\end{array}$ & $\begin{array}{l}\text { Formwork/falsework company technician (Product } \\
\text { designer, commercial technician, aftersales, or } \\
\text { similar) }\end{array}$ \\
\hline Who designs the project? & Project designer & $\begin{array}{l}\text { Engineer in design company or lecturer with } \\
\text { experience on civil structural design }\end{array}$ \\
\hline $\begin{array}{l}\text { Who executes the project } \\
\text { designed and use the } \\
\text { formwork/ falsework? }\end{array}$ & $\begin{array}{l}\text { Construction } \\
\text { company }\end{array}$ & $\begin{array}{c}\text { Manager or supervisor in a civil construction } \\
\text { company (Project based management, office based } \\
\text { management, or similar) }\end{array}$ \\
\hline
\end{tabular}

After the definition of the main groups of interest, the next step was to select the countries to study and compare. The selection of Spain and the United Kingdom was not random. According to the statistics from International Monetary Fund (IMF, 2018) there are 21 Hispanic countries around the world, and Spain and Mexico are the most important between them. In the same way there are 14 countries considered as Anglo-Saxon countries, and United Kingdom and United States of America are considered the most representative from them. Then influence of Hispanic and AngloSaxon culture around the world is considerable.

According to that, Spain and United Kingdom were selected as representative and homogeneous countries, because they have common legislation, as Directives from European Union, but different traditions due to their Hispanic and Anglo-Saxon roots and culture.

Once the groups of interest and the countries under study were defined, five interest groups were obtained in total. Abbreviation forms for these groups of interest were included in the results for a better presentation of them. Description of abbreviation forms were included in the following Table 2.

\begin{tabular}{lc}
\multicolumn{2}{c}{ Table 2. Abbreviations of group of interest. Source: Self-elaboration. } \\
\hline Group of interest & Abbreviation \\
\hline Project designer from Spain & PD SP \\
Project designer from United Kingdom & PD UK \\
Construction company Spain & CC SP \\
Construction company United Kingdom & CC UK \\
Formwork manufacturing company (both countries) & FFC \\
\hline
\end{tabular}

It is highlighted that International Formwork \& Falsework companies manufacture similar products in countries studied, so to separate the answers obtained from experts of this companies by countries was not considered necessary. There are the similar suppliers companies in both countries. In the case of construction companies and project designers, although they are also international companies, their scope is usually more local. In consequence, the answers of these groups of interest were separate in order to compare the results from United Kingdom and Spain.

Table 3 presents the descriptions of the International Formwork \& Falsework companies' participant content: role in the market, staff of the company, number of countries where they have presence, and job of the experts selected. Cited descriptions are included in Table 3 where companies were ranked according to their total staff.

The next phase of the research was focused on designing an ah-doc questionnaire that would serve as a research tool for data collection. Thus, a Likert-scale questionnaire (Likert, 1932) was designed in order to collect the opinion from the expert in the groups pre-defined.. Likert scale questionnaire has been demonstrated as a very useful tool in previous papers about occupational health and safety in construction (Gittleman et al., 2010; Ismail, Doostdar, \& Harun, 2012; Meliá, Mearns, Silva, \& Lima, 2008) this is the main reason of the application of this methodology in the present work. This questionnaire presented a 5-point scale from strongly disagree (1) to strongly agree (5) and it was based on the study developed by Tymvios \& Gambatese (2016). 
Table 3. Ranking and descriptions of selected companies. Source: Self-elaboration

\begin{tabular}{|c|c|c|c|c|c|c|}
\hline Company & Ranking & Staff & Countries & \multicolumn{2}{|c|}{$\begin{array}{l}\text { Presence around } \\
\text { the world }\end{array}$} & \multirow[t]{2}{*}{ Expert job } \\
\hline \multirow{14}{*}{$\begin{array}{l}\text { Formwork/ } \\
\text { falsework }\end{array}$} & \multirow{4}{*}{1} & \multirow{4}{*}{$>5000$} & \multirow{4}{*}{75} & Africa & 7 & \\
\hline & & & & America & 6 & \multirow{3}{*}{ Project design } \\
\hline & & & & Asia & 25 & \\
\hline & & & & Europe & 37 & \\
\hline & \multirow{5}{*}{2} & \multirow{5}{*}{$>3000$} & \multirow{4}{*}{73} & Africa & 9 & Product design \\
\hline & & & & America & 18 & \multirow{3}{*}{$R \& D$} \\
\hline & & & & Asia & 18 & \\
\hline & & & & Europe & 37 & \\
\hline & & & \multirow{3}{*}{25} & America & 7 & Traınıng \& educatıon \\
\hline & \multirow[t]{3}{*}{3} & \multirow[t]{2}{*}{$>2000$} & & Asia & 6 & \multirow{2}{*}{ Commercial technician } \\
\hline & & & & Europe & 12 & \\
\hline & & \multirow{3}{*}{$>500$} & \multirow{3}{*}{13} & Africa & 2 & \multirow[t]{3}{*}{ Aftersales } \\
\hline & \multirow[t]{2}{*}{4} & & & America & 5 & \\
\hline & & & & Europe & 6 & \\
\hline
\end{tabular}

The questionnaires were designed to be simple and brief. Once the preliminary version of the questionnaire was obtained, the content validity was evaluated. For this purpose, eight different experts on Occupational Health and Safety in Construction checked the suitability and quality of the questions. Suggestions of the experts about the language level, comprehensiveness or item content were used to redesign the questionnaire and obtain the final version of the questionnaire.

The final questionnaire contained 17 items, grouped in three different sections: a) Design phase, b) Construction phase, and c) Legal issues. All the items do not affect directly in the same proportion the three groups studied. For example, first question in the design phase affects directly designers group and formwork companies group. Contractors are not explicit included in the item but indirectly contractors group will be affected by the performance of the item issue by the other two groups directly affected. Then contractors will have their own opinion about the first question issue too.

Once the final questionnaire was obtained, the data collection phase began. Different international companies were contacted according to the different groups of interest. In order to ensure anonymity and confidentiality, no personal data identifying the respondent was recorded. In addition, a brief summary about the research context and the objective was included at the beginning of the questionnaire. Likewise, instructions were included on how to properly complete the questionnaire. The interviewees were asked the maximum honesty, since their anonymity was guaranteed. Due to the sensitivity of the data and in order to ensure the understanding of the instructions, in addition of the traditional surveys method as mailing or virtual surveys, possibility of interview was provided to the respondents. Face to face interaction also provided the interviewer with the opportunity to clarify questions about the content of the items.

A total amount of 250 questionnaires were delivered between the selected groups of interest. Finally, 204 filled questionnaires were collected, which is response rate of $81.6 \%$. Respondent professionals accumulate a total number of 2777 years of experience with an average of 13.61 years of experience per professional. A percentage of $88.2 \%$ of respondent were male, and $11.8 \%$ female. It is remarkable that $90 \%$ of the professionals had training in Health and Safety (H\&S), and only $10 \%$ had no any background in Health and Safety training (Table 4).

\begin{tabular}{|c|c|c|c|}
\hline & \multicolumn{3}{|c|}{ United } \\
\hline & Spain & Kingdom & Total \\
\hline Project Designer & 20 & 16 & 36 \\
\hline Construction Company & 54 & 44 & 98 \\
\hline Formwork/falsework company & \multicolumn{2}{|r|}{70} & 70 \\
\hline Total & 144 & 60 & 204 \\
\hline$\%$ Male & 86.8 & 91.7 & 88.2 \\
\hline \%Female & 13.2 & 8.3 & 11.8 \\
\hline \%Training in $\mathrm{H} \& \mathrm{~S}$ & 88.8 & 98.3 & 95.6 \\
\hline Average of experience (years) & 12.42 & 16.48 & 13.61 \\
\hline
\end{tabular}

In the last phase of the study, the collected data were analyzed by applying different statistical tools. On the one hand, the questionnaire reliability was assessed by Cronbach analysis. It was found that the Cronbach's alpha for the 
questionnaire was 0.61 . Although this value is not too high and could be considered that shows moderate reliability (Hinton, McMurray, \& Brownlow, 2014), Nunally \& Bernstein (1994) stated that values of 0.60 to 0.70 are acceptable in exploratory research. On the other hand, descriptive statistical measures were used to analyze the data and median test and kruskall-wallis test were used in order to test specific hypothesis.

Results

Results from Hispanic and Anglo-Saxon respondents were analyzed along the three item-categories. Mean, median, mode and variance were calculated for all the items' answer. In addition results from median test and Kruskall-Wallis test were showed too.

\section{Design phase}

Regard to question focused on the design phase of the construction project it is remarkable that big differences were found between Spanish Project designers and British Project designers in some questions. While majority of Spanish designers would not ask the formwork manufacturing company for advice while they are designing the structure (Q1, Mean=1.50; Var=0.474), British designers use to ask them more frequently (Q1, Mean=3.06; Var=1.396). In a similar way, project designers in UK, considered that when formwork/falsework is being designed safety is considered as a very important design factor, (Q4, Mean=4.38; Var=0.517), but Spanish project designers did not agree with that (Q4, Mean=2.40, Var=0.884). In contrast both groups of interest obtained similar level of agreement about the importance of final cost as a design factor of formwork/falsework (Q6, Table 5).

Construction companies' opinion is different between countries studied in some aspects of Design phase. Formwork selection is up to the construction company in UK because the majority of projects do not specify type of the formwork (Q3, Mean=4.48; Var=0.674). However the rate of agreement about that the type of formwork is included in the documentation of the project is lower, in Spanish construction companies (Q3, Mean=3.63; Var=0.996). Similarly, safety is considered as a more important formwork's design factor by experts from construction companies in UK, than experts from Spanish construction companies.

In Figure 2 shows the percentage of respondents who agree or strongly agree at items related with design phase. It is remarkable that highest level of agreement was obtained in items related with productivity and final cost during the design phase of the formwork/falsework $(\mathrm{Q} 5, \mathrm{Q6})$. In the opposite, items Q2, and Q4 obtained the biggest differences between professionals asked. It must be highlighted that in some items bigger differences were found between groups of interest from the same country than between same group of interest from different countries.

Figure 2. Percentage of respondents who agree or strongly agree in design phase items. Source: Self-elaboration.

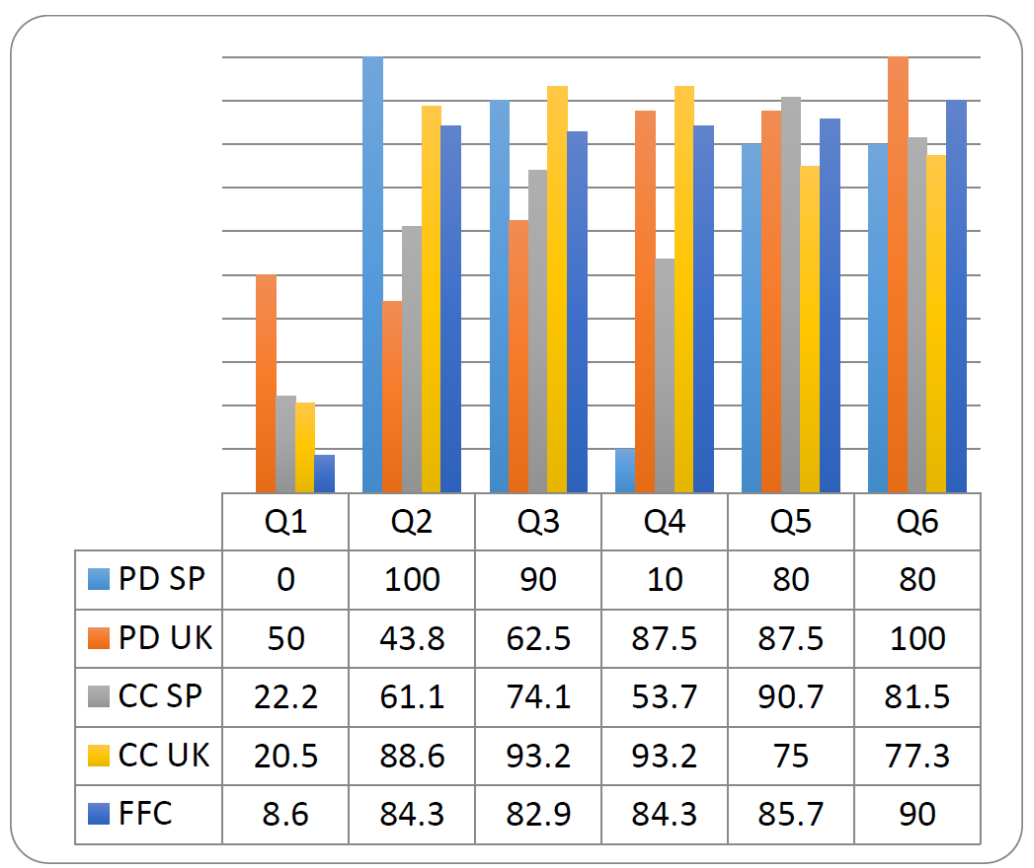


Table 5. Design phase statistics values. Source: Self-elaboration.

\begin{tabular}{|c|c|c|c|c|c|c|c|c|c|}
\hline & \multirow[b]{2}{*}{ Design phase } & \multicolumn{4}{|c|}{ Spain } & \multicolumn{4}{|c|}{ UK } \\
\hline & & Mean & Median & Mode & Variance & Mean & Median & Mode & Variance \\
\hline \multicolumn{10}{|l|}{ Q1 } \\
\hline & $\begin{array}{l}\text { The project designer would ask the } \\
\text { formwork manufacturing company } \\
\text { for advice while they are designing } \\
\text { the structure }\end{array}$ & & & & & & & & \\
\hline & Project designer & 1.50 & 1 & 1 & 0.474 & 3.06 & 3.50 & 4 & 1.396 \\
\hline & Construction company & 2.67 & 2 & 2 & 0.991 & 2.39 & 2 & 2 & 1.684 \\
\hline & Formwork manufacturing company & 2.07 & 2 & 2 & 0.821 & 2.07 & 2 & 2 & 0.821 \\
\hline \multicolumn{10}{|c|}{ 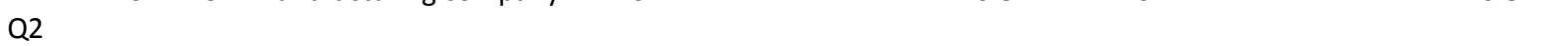 } \\
\hline & $\begin{array}{l}\text { The project designer designs the } \\
\text { structure without consulting the } \\
\text { formwork/falsework manufacturing } \\
\text { company. When the design is } \\
\text { finished the construction company } \\
\text { asks the formwork/falsework } \\
\text { manufacturer for constructive } \\
\text { solutions to suit the structure as } \\
\text { designed. }\end{array}$ & & & & & & & & \\
\hline & Project designer & 4.20 & 4 & 4 & 0.168 & 3.31 & 3 & 3 & 1.029 \\
\hline & Construction company & 3.41 & 4 & 4 & 1.073 & 4.02 & 4 & 4 & 0.767 \\
\hline & Formwork manufacturing company & 4.19 & 4 & 5 & 0.849 & 4.19 & 4 & 5 & 0.849 \\
\hline \multicolumn{10}{|c|}{$x_{0}$} \\
\hline & $\begin{array}{l}\text { The majority of projects do not } \\
\text { specify type of the } \\
\text { formwork/falsework in the project's } \\
\text { documentation. Formwork/falsework } \\
\text { selection is up to the construction } \\
\text { company. }\end{array}$ & & & & & & & & \\
\hline & Project designer & 4.20 & 4 & 4 & 0.379 & 3.81 & 4 & 4 & 0.829 \\
\hline & Construction company & 3.63 & 4 & 4 & 0.996 & 4.48 & 5 & 5 & 0.674 \\
\hline & Formwork manufacturing company & 4.10 & 4 & 4 & 0.555 & 4.10 & 4 & 4 & 0.555 \\
\hline \multicolumn{10}{|c|}{ 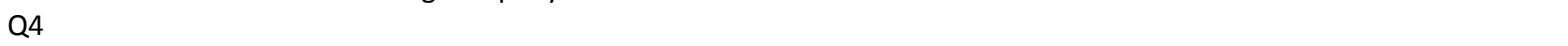 } \\
\hline & \multicolumn{9}{|l|}{$\begin{array}{l}\text { When formwork/falsework is being } \\
\text { designed safety is considered as a } \\
\text { very important design factor. }\end{array}$} \\
\hline & Project designer & 2.40 & 2.5 & 3 & 0.884 & 4.38 & 4.50 & 5 & 0.517 \\
\hline & Construction company & 3.44 & 4 & 4 & 1.040 & 4.48 & 5 & 5 & 0.395 \\
\hline & Formwork manufacturing company & 4.09 & 4 & 4 & 0.601 & 4.09 & 4 & 4 & 0.601 \\
\hline \multicolumn{10}{|c|}{ (1) } \\
\hline & \multicolumn{9}{|l|}{$\begin{array}{l}\text { When formwork/falsework is being } \\
\text { designed productivity is considered } \\
\text { as a very important design factor. }\end{array}$} \\
\hline & Project designer & 3.80 & 4 & 4 & 2.274 & 4.13 & 4 & 4 & 0.383 \\
\hline & Construction company & 4.19 & 4 & 4 & 0.585 & 4.07 & 4 & 4 & 0.809 \\
\hline & Formwork manufacturing company & 4.27 & 4 & 4 & 0.490 & 4.27 & 4 & 4 & 0.490 \\
\hline \multicolumn{10}{|c|}{ 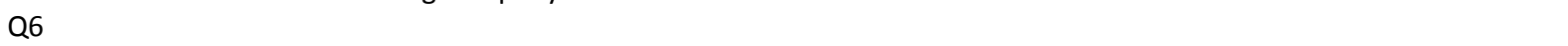 } \\
\hline & \multicolumn{9}{|l|}{$\begin{array}{l}\text { When a formwork/falsework is being } \\
\text { designed final cost is considered as a } \\
\text { very important design factor. }\end{array}$} \\
\hline & Project designer & 4.00 & 5 & 5 & 2.526 & 4.31 & 4 & 4 & 0.229 \\
\hline & Construction company & 4.22 & 4 & 4 & 0.744 & 3.95 & 4 & 4 & 0.928 \\
\hline & Formwork manufacturing company & 4.36 & 4 & 5 & 0.436 & 4.36 & 4 & 5 & 0.436 \\
\hline
\end{tabular}

\section{Construction phase}

Table 6 displays the responses to survey questions directed at construction phase of the project. Items $(Q 7, Q 8)$ show that all groups considered that customer do not always choose the safest formwork/falsework, and they prefer the cheapest one. No differences were found between countries about the statement that the user always follows the manufacturer's instruction about the product (Q9), all groups trend to agree with that. Similarly, all groups agreed that technical advices from manufacturers include safety issues. 
Table 6. Construction phase statistics values. Source: Self-elaboration.

\begin{tabular}{|c|c|c|c|c|c|c|c|c|c|}
\hline \multirow[b]{2}{*}{ Item } & \multirow[b]{2}{*}{ Construction phase } & \multicolumn{4}{|c|}{ Spain } & \multicolumn{4}{|c|}{ UK } \\
\hline & & Mean & Median & Mode & Variance & Mean & Median & Mode & Variance \\
\hline \multirow[t]{4}{*}{ Q7 } & $\begin{array}{l}\text { The formwork/falsework } \\
\text { customer chooses always } \\
\text { the safest one. }\end{array}$ & & & & & & & & \\
\hline & Project designer & 1.80 & 3 & 1 & 0.589 & 2.69 & 3 & 2 & 0.496 \\
\hline & Construction company & 2.93 & 3 & 3 & 1.096 & 3.14 & 3 & 3 & 1.051 \\
\hline & $\begin{array}{r}\text { Formwork manufacturing } \\
\text { company }\end{array}$ & 2.04 & 2 & 2 & 0.534 & 2.04 & 2 & 2 & 0.534 \\
\hline \multirow[t]{4}{*}{ Q8 } & $\begin{array}{l}\text { The formwork/falsework } \\
\text { customer chooses always } \\
\text { the cheapest one. }\end{array}$ & & & & & & & & \\
\hline & Project designer & 3.60 & 4 & 4 & 1.305 & 3.06 & 3 & 3 & 0.863 \\
\hline & Construction company & 3.52 & 3 & 3 & 1.059 & 3.23 & 3 & 3 & 0.924 \\
\hline & $\begin{array}{r}\text { Formwork manufacturing } \\
\text { company }\end{array}$ & 3.84 & 4 & 4 & 0.569 & 3.84 & 4 & 4 & 0.569 \\
\hline \multirow[t]{4}{*}{ Q9 } & $\begin{array}{l}\text { The user always follows } \\
\text { the manufacturer's } \\
\text { instructions about the } \\
\text { product. }\end{array}$ & & & & & & & & \\
\hline & Project designer & 2.99 & 3 & 3 & 0.594 & 3.13 & 3 & 3 & 0.650 \\
\hline & Construction company & 3.59 & 4 & 4 & 0.981 & 3.52 & 4 & 4 & 0.860 \\
\hline & $\begin{array}{r}\text { Formwork manufacturing } \\
\text { company }\end{array}$ & 2.99 & 3 & 3 & 0.594 & 2.99 & 3 & 3 & 0.594 \\
\hline \multirow[t]{4}{*}{ Q10 } & $\begin{array}{l}\text { Technical advice from } \\
\text { formwork/falsework } \\
\text { companies to users } \\
\text { includes advice about } \\
\text { safety issues related with } \\
\text { use of the } \\
\text { formwork/falsework. }\end{array}$ & & & & & & & & \\
\hline & Project designer & 4.16 & 4 & 4 & 0.540 & 3.75 & 4 & 4 & 0.200 \\
\hline & Construction company & 3.30 & 3 & 4 & 0.944 & 3.95 & 4 & 4 & 0.789 \\
\hline & $\begin{array}{r}\text { Formwork manufacturing } \\
\text { company }\end{array}$ & 4.16 & 4 & 4 & 0.540 & 4.16 & 4 & 4 & 0.540 \\
\hline \multirow[t]{4}{*}{ Q11 } & $\begin{array}{l}\text { Formwork/falsework } \\
\text { suppliers are the same } \\
\text { suppliers for the rest of } \\
\text { temporary equipment (e.g. } \\
\text { scaffolds or hoists) }\end{array}$ & & & & & & & & \\
\hline & Project designer & 2.40 & 2 & 2 & 0.253 & 2.69 & 3 & 3 & 0.229 \\
\hline & Construction company & 2.81 & 3 & 3 & 0.848 & 2.07 & 2 & 2 & 0.577 \\
\hline & $\begin{array}{r}\text { Formwork manufacturing } \\
\text { company }\end{array}$ & 2.77 & 3 & 2 & 0.990 & 2.77 & 3 & 2 & 0.990 \\
\hline \multirow[t]{4}{*}{ Q12 } & $\begin{array}{l}\text { Formwork/falsework } \\
\text { manufacturers provide } \\
\text { training in health and } \\
\text { safety to their customers } \\
\text { in the use of their products }\end{array}$ & & & & & & & & \\
\hline & Project designer & 2.20 & 2 & 2 & 0.800 & 3.13 & 3 & 3 & 0.383 \\
\hline & Construction company & 3.00 & 3 & 3 & 0.847 & 3.11 & 3 & 3 & 0.754 \\
\hline & $\begin{array}{r}\text { Formwork manufacturing } \\
\text { company }\end{array}$ & 4.07 & 4 & 4 & 0.908 & 4.07 & 4 & 4 & 0.908 \\
\hline \multirow[t]{4}{*}{ Q13 } & $\begin{array}{l}\text { Formwork/falsework } \\
\text { manufacturers provide the } \\
\text { customer with qualified } \\
\text { technicians to erect, use } \\
\text { and dismantle the } \\
\text { formwork/falsework and } \\
\text { their auxiliary equipment. }\end{array}$ & & & & & & & & \\
\hline & Project designer & 1.50 & 1 & 1 & 0.474 & 3.00 & 3 & 3 & 0.267 \\
\hline & Construction company & 2.93 & 3 & 3 & 1.043 & 2.30 & 2 & 1 & 1.190 \\
\hline & $\begin{array}{r}\text { Formwork manufacturing } \\
\text { company }\end{array}$ & 3.66 & 4 & 4 & 1.040 & 3.66 & 4 & 4 & 1.040 \\
\hline
\end{tabular}


In the opposite, big differences were found in the results about the training in health and safety provided by the supplier to the customer (Q12). Cited item was scored by Spanish Project designers with low values (Mean =2.20; Var=0.800), construction companies scored it more positively, and formwork manufacturing companies obtained the highest values (Mean=4.07; Var=0.908).

Figure 3. Percentage of respondents who agree or strongly agree in construction phase items. Source: Self-elaboration.

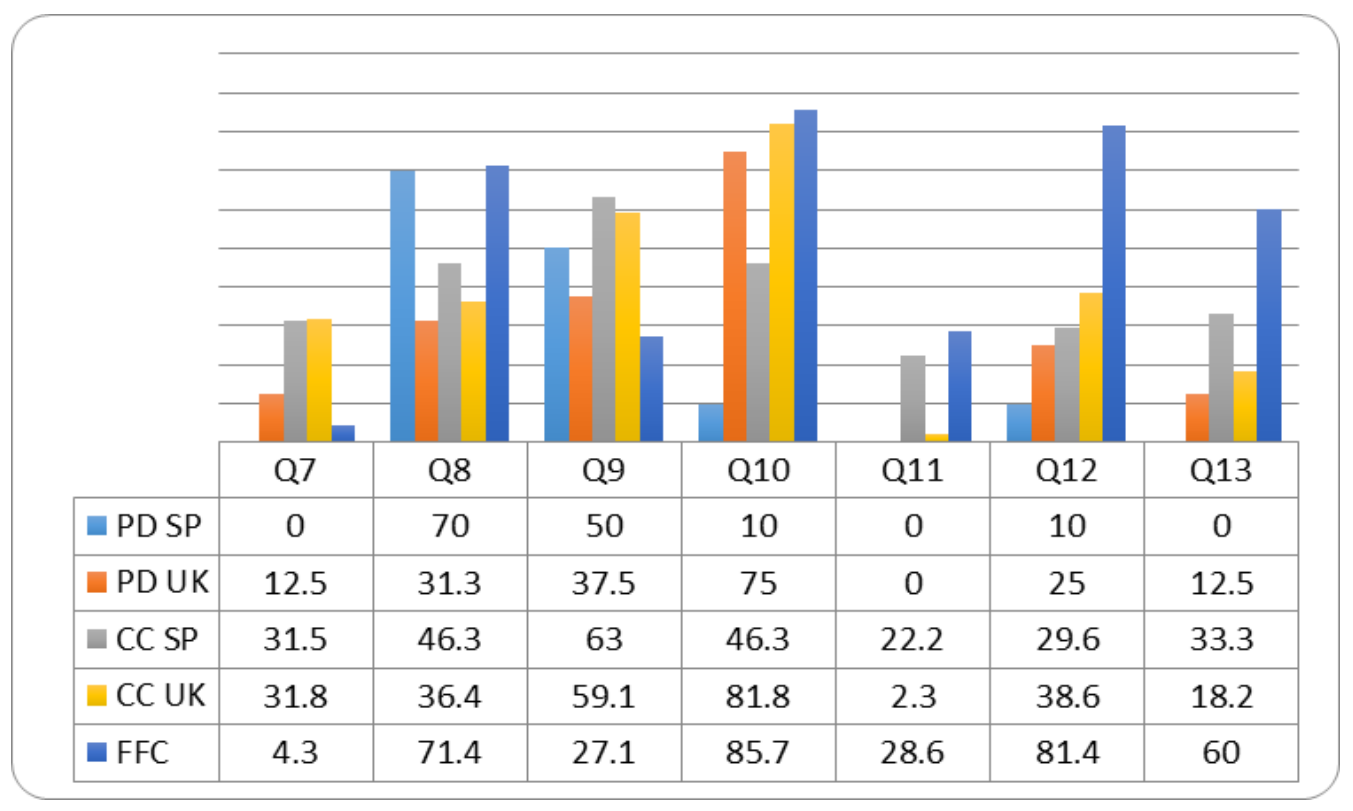

Figure 3 provides the responses from professionals who agree or strongly agree with statements from question about construction phase. No differences between countries were observed in the level of agreement of questions about the election factors of the formwork $(Q 7, Q 8)$. In opinion of all group of professional asked, independently of the country, safety is not the most valuated factor when a customer choose a formwork/falsework, because prize obtained highest rates of agreement.

However, significant differences were found between countries and groups about the training, and technicians provided by suppliers (Q12, Q13). Formwork manufacturers suggest that they provide training and technical support but the perception of the customer is not the same. Differences could be motivated due to a bad communication between supplier and customer.

\section{Legal issues}

In this section legal issues about design and use of formwork were addressed. Experts were asked about their opinion about the possible health and safety improvements derivative from the creation of compulsory and non-compulsory standards (International Standard Organization, British Standard, Spanish Standard, or similar).

As can be observed in Table 7, all mean values calculated were higher than three, and many items mode value was four or five.

Experts' participant in this research considered the compulsory standards more effective if they compare them with non-compulsory standards. In particular, the statement that compulsory standard about use of formwork/falsework would improve the health and safety for the workers, obtained the highest rates of agreement by every stakeholders asked (Q16). Results from cited question were higher in Spain that in UK.

Although means showed in Table 7 were similar between countries studied, percentage of respondents who agree or strongly agree showed some differences. In the group of project designers can be observed that Spanish Designers are partakers of standards, those British designers. Although the trend is similar in the rest of groups, smaller differences between countries were found in the analysis of construction companies results. It may be said that, lack of specific legislation has a negative impact in the health and safety levels of the design and use of formworks. 


\begin{tabular}{|c|c|c|c|c|c|c|c|c|c|}
\hline \multirow[b]{2}{*}{ Item } & \multirow[b]{2}{*}{ Legal issues } & \multicolumn{4}{|c|}{ Spain } & \multicolumn{4}{|c|}{ UK } \\
\hline & & Mean & Median & Mode & Variance & Mean & Median & Mode & Variance \\
\hline \multirow[t]{4}{*}{ Q14 } & $\begin{array}{l}\text { A compulsory standard } \\
\text { about } \\
\text { formwork/falsework } \\
\text { design and } \\
\text { manufacture would } \\
\text { improve health and } \\
\text { safety in the final } \\
\text { formwork/falsework as } \\
\text { a product. }\end{array}$ & & & & & & & & \\
\hline & Project designer & 3.90 & 4 & 4 & 1.147 & 3.81 & 4 & 4 & 0.429 \\
\hline & Construction company & 3.94 & 4 & 4 & 0.899 & 4.61 & 4 & 4 & 0.614 \\
\hline & $\begin{array}{r}\text { Formwork } \\
\text { manufacturing } \\
\text { company }\end{array}$ & 4.26 & 4 & 5 & 0.629 & 4.26 & 4 & 5 & 0.629 \\
\hline \multirow[t]{4}{*}{ Q15 } & $\begin{array}{l}\text { A non-compulsory } \\
\text { specific standard (ISO, } \\
\text { BS or similar) about } \\
\text { formwork/falsework } \\
\text { design and } \\
\text { manufacture would } \\
\text { improve health and } \\
\text { safety in the final } \\
\text { formwork/falsework as } \\
\text { a product. }\end{array}$ & & & & & & & & \\
\hline & Project designer & 3.20 & 3.5 & 4 & 0.800 & 3.13 & 3 & 3 & 0.517 \\
\hline & Construction company & 3.00 & 3 & 3 & 0.991 & 3.39 & 3 & 3 & 0.847 \\
\hline & $\begin{array}{r}\text { Formwork } \\
\text { manufacturing } \\
\text { company }\end{array}$ & 3.26 & 3 & 3 & 1.005 & 3.26 & 3 & 3 & 1.005 \\
\hline \multirow[t]{4}{*}{ Q16 } & $\begin{array}{l}\text { A compulsory standard } \\
\text { about } \\
\text { formwork/falsework } \\
\text { use would improve } \\
\text { health and safety for } \\
\text { the } \\
\text { formwork/falsework } \\
\text { workers. }\end{array}$ & & & & & & & & \\
\hline & Project designer & 4.50 & 4.5 & 4 & 0.263 & 4.00 & 4 & 4 & 0.267 \\
\hline & Construction company & 4.00 & 4 & 4 & 0.824 & 3.66 & 4 & 4 & 1.067 \\
\hline & $\begin{array}{r}\text { Formwork } \\
\text { manufacturing } \\
\text { company }\end{array}$ & 4.37 & 5 & 5 & 0.643 & 4.37 & 5 & 5 & 0.643 \\
\hline \multirow[t]{4}{*}{ Q17 } & $\begin{array}{l}\text { A non-compulsory } \\
\text { specific standard (ISO, } \\
\text { BS or similar) about } \\
\text { formwork/falsework } \\
\text { use would improve } \\
\text { health and safety for } \\
\text { the } \\
\text { formwork/falsework } \\
\text { workers. }\end{array}$ & & & & & & & & \\
\hline & Project designer & 3.40 & 4 & 4 & 2.147 & 2.94 & 3 & 3 & 0.596 \\
\hline & Construction company & 3.07 & 3 & 3 & 1.043 & 3.20 & 3 & 3 & 0.818 \\
\hline & $\begin{array}{r}\text { Formwork } \\
\text { manufacturing } \\
\text { company }\end{array}$ & 3.49 & 4 & 4 & 1.239 & 3.49 & 4 & 4 & 1.239 \\
\hline
\end{tabular}

\section{Statistical test}

Quantitative statistical tools were carried on for project designer and construction company professionals in order to test the following hypothesis: 
Hypothesis 1 (H1): Median of the item is the same in both countries studied, Spain and UK

Hypothesis 2 (H2): Distribution of the item is the same in both countries studied, Spain and UK

Hypothesis 1 was validated using the median test, Hypothesis 2 was validated using Kruskal Wallis test. Results of both tests are shown in Table 8. Results were obtained with a significance level of 0.05 , and a confidence interval of $95 \%$.

Statistical test results showed that more similarities between median, and distributions of respondent were found between construction companies from UK and Spain than project designers from cited countries. In the case of project designers, $\mathrm{H} 1$ was rejected in the $41 \%$ of items, while for construction companies $\mathrm{H} 1$ was rejected only in the $25 \%$ of the items analyzed.

Hypothesis 2 was rejected in the $47 \%$ of the items for project designers, while for construction companies was rejected in the $41 \%$ of the items.

Table 8. Statistical results from Median test and Kruskall-Wallis test. Source: Self-elaboration.

\begin{tabular}{|c|c|c|c|c|c|c|c|c|c|}
\hline \multirow{2}{*}{\multicolumn{2}{|c|}{ Test Professional Group }} & \multicolumn{4}{|c|}{ Project designer } & \multicolumn{4}{|c|}{ Construction company } \\
\hline & & \multicolumn{2}{|c|}{ Median test $(\mathrm{H} 1)$} & \multicolumn{2}{|c|}{ Kruskall-Wallis test $(\mathrm{H} 2)$} & \multicolumn{2}{|c|}{ Median test $(\mathrm{H} 1)$} & \multicolumn{2}{|c|}{$\begin{array}{c}\text { Kruskall-Wallis } \\
\text { test }(\mathrm{H} 2)\end{array}$} \\
\hline & Item & Sig & Decision & Sig & Decision & Sig & Decision & Sig & Decision \\
\hline \multirow{6}{*}{$\begin{array}{l}\text { Design } \\
\text { phase }\end{array}$} & Q1 & 0.003 & Rejected & 0.000 & Rejected & 0.035 & Accepted & 0.056 & Accepted \\
\hline & Q2 & 0.549 & Accepted & 0.003 & Rejected & 0.036 & Accepted & 0.001 & Rejected \\
\hline & Q3 & 0.739 & Accepted & 0.177 & Accepted & 0.000 & Rejected & 0.000 & Rejected \\
\hline & Q4 & 0.000 & Rejected & 0.000 & Rejected & 0.000 & Rejected & 0.000 & Rejected \\
\hline & Q5 & 0.343 & Accepted & 0.781 & Accepted & 0.363 & Accepted & 0.723 & Accepted \\
\hline & Q6 & 0.086 & Accepted & 0.399 & Accepted & 0.250 & Accepted & 0.225 & Accepted \\
\hline \multirow{7}{*}{$\begin{array}{l}\text { Construction } \\
\text { phase }\end{array}$} & Q7 & 0.024 & Accepted & 0.002 & Rejected & 0.972 & Accepted & 0.363 & Accepted \\
\hline & Q8 & 0.236 & Accepted & 0.116 & Accepted & 0.321 & Accepted & 0.173 & Accepted \\
\hline & Q9 & 0.453 & Accepted & 0.161 & Accepted & 0.810 & Accepted & 0.612 & Accepted \\
\hline & Q10 & 0.000 & Rejected & 0.000 & Rejected & 0.013 & Rejected & 0.000 & Rejected \\
\hline & Q11 & 0.000 & Rejected & 0.090 & Accepted & 0.000 & Rejected & 0.000 & Rejected \\
\hline & Q12 & 0.230 & Accepted & 0.002 & Rejected & 0.348 & Accepted & 0.390 & Accepted \\
\hline & Q13 & 0.000 & Rejected & 0.000 & Rejected & 0.091 & Accepted & 0.005 & Rejected \\
\hline \multirow{4}{*}{$\begin{array}{l}\text { Legal } \\
\text { issues }\end{array}$} & Q14 & 0.074 & Accepted & 0.362 & Accepted & 0.265 & Accepted & 0.031 & Rejected \\
\hline & Q15 & 0.257 & Accepted & 0.683 & Accepted & 0.232 & Accepted & 0.056 & Accepted \\
\hline & Q16 & 0.018 & Rejected & 0.009 & Rejected & 0.568 & Accepted & 0.111 & Accepted \\
\hline & Q17 & 0.007 & Rejected & 0.105 & Accepted & 0.589 & Accepted & 0.587 & Accepted \\
\hline
\end{tabular}

Discussion

Data analysis confirmed some differences between groups of interest studied. Findings identify many different perceptions between builders and designers, especially during the construction phase. These results are aligned with previous studies (Zhao, McCoy, Kleiner, Mills, \& Lingard, 2016). An explanation can be found in the fact that perceptions surveyed from the groups identified, are affected by their role and responsibilities through the phases included in a construction project (Gambatese et al., 2008).

On one hand, the majority of the results obtained from Spanish project designers are in line with the statement that safety focus for designers has been exclusive to the end-user personnel of the facility designed, with disregard for the personnel constructing it (Gambatese, 2000). However, the influence of design decisions affects construction methods used in the field (Toole, 2005). Although traditional view on construction safety is that it lies solely on construction companies (Tymvios \& Gambatese, 2016), some studies revealed that stakeholders in the design phase have great influence on Occupational Safety (Gambatese et al., 2008). 
Otherwise, in the design phase, it can be observed that designers from the UK use to ask formwork manufacturer about safety, in contrast with designers from Spain where this practice is less frequent. Another significant difference between countries is that the majority of designers and construction companies in the UK considered safety from the beginning of the design process as a very important factor. These view about the safety concept could lead to better development of the PtD concept, and in consequence, a mitigation of the Occupational Hazards linked to design (Zhao, Hwang, \& Pheng Low, 2014). The adequate implementation of PtD concept is one of the reasons because the United Kingdom is one of the countries with lower accident rates (Eurostat, 2015). In U.S construction where accidents rates are similar to Spain (BLS, 2013; Eurostat, 2015), it has been detected a lack of understanding of what is involved when designers are asked to practice PtD (Behm, 2004).

In the construction phase items, more differences than similarities were found between project designers and construction companies. A reason to explain the differences could be that designers frequently are lack of hazards awareness during the construction phase and unfamiliar with safety control measures (Mills \& Glass, 2009). The difference perceptions identified due to gaps between the work system is similar to results obtained in previous research (Zhao, McCoy, Kleiner, Smith-Jackson, \& Liu, 2015). Similarly, differences found in the results, seems to be in consonance with the fact that, fragmentation of the technical roles and responsibilities of the construction industry, create differences in orientation and working style and process, but risk mitigation is an integral effort that requires inputs from designers, contractors, and suppliers (Floyd \& Liggett, 2010). Then, an alignment of the objectives and effective communication between stakeholders are essential to safety conditions of the projects (Du et al., 2016). Finally, in the section about legal issues, trends were similar between countries, and group of interest.

Conclusions

Although construction issues addressed in this research obtained different values depending on the stakeholder or group of interest and country, majority of the items do not scored difference of means values bigger than absolute value of one, between groups of respondent. Then, differences in the construction procedures and use and design of formwork/falsework between Hispanic and Anglo-Saxon countries studied are not especially significant.

In the design phase of the construction project, lack of interaction between designers and formworks/falseworks companies, were detected by every stakeholder, in both countries. In addition, absence of specification of the type of the formwork/falsework in the projects was pointed too as a usual practice in Spain and United Kingdom. Better communication between stakeholders in the design phase, could improve the health and safety levels in construction projects.

In relation to the design phase of the formwork/falsework, final cost of the product was considered the most important factor while the product is being designed. Productivity factor was considered an important factor too. In contrast safety factor, obtained the lowest score. These results were corroborated by results obtained in the construction phase were the users prefer the cheapest formwork before the safest one. According to that, a safety formwork is not considered by respondents as an effective economical tool, although the saving obtained by a good performance of occupational safety it has been demonstrated very powerful due to the high economical cost of the accidents.

Special attention must be given to training in health and safety to formwork users, and the provision of qualified technicians by manufacturers. In questions about this issue were found the biggest difference between manufacturers and constructors perception. Absence of training in health safety of the users from the manufacturers was pointed from both groups in the current development of construction works.

In relation with the legal issues studied, all the groups considered that standards about design and use of formwork, would improve health and safety levels. Possible improvements as result as creation of new standards, obtained better values from a Hispanic country than an Anglo-Saxon.

Implementation of multi-level organizational surveys could identify major occupational safety issues of concern. Feedback between stakeholders can potentially improve the occupational safety levels in the sector of formwork/falsework.

\section{Limitations of the study}

The present study was limited in some ways. Although the most important international commercial formwork companies were represented in the research, other companies refuse the invitation to participate. Similar limitation is 
observed in the construction companies professionals. Although construction companies selected are international companies with presence in several countries, they are only a sample from the population studied, in two countries as Spain and United Kingdom. Little number of project designers selected in comparison with the other two categories of respondent, was due to the little number of designers existing.

\section{Impact on the industry}

Identification of the sector's needing through the opinion of the main participants in the formwork trade is an important step to improve the health and safety levels. Improvement according construction participants' perception will have a positive impact in every organization implied. Knowledge of the others participants perceptions could facilitate the communication and interaction between parts implied and generate a positive cooperation between groups in order to improve the health and safety levels from the beginning of the construction at the design phase.

\section{Future Research}

Future research should include a larger sample of respondents in order to avoid current limitations. In addition, to improve communication and coordination among construction stakeholders, the usual communication procedures among companies in countries with different accident rates should be studied and compared.

References

Behm, M. (2004). Establishing the link between construction fatalities and disabling injuries and the design for construction safety concept (Doctoral Thesis). Oregon State University.

Behm, M. (2005). Linking construction fatalities to the design for construction safety concept. Safety Science, 43(8), 589-611. https://doi.org/10.1016/j.ssci.2005.04.002

BLS. (2011). National census of fatal occupational injuries in 2010 (Preliminary Results) (No. USDL-11-1247). Retrieved from Bureau of Labor Statistics. U.S. Department of Labor website: https://www.bls.gov/news.release/archives/cfoi_08252011.pdf

BLS. (2013). Fatal occupational injuries in 2013 - chart package. Retrieved from https://www.bls.gov/iif/oshwc/cfoi/cfch0012.pdf

Borman, W. C. (1997). $360^{\circ}$ ratings: An analysis of assumptions and a research agenda for evaluating their validity. Human Resource Management Review, 7(3), 299-315. https://doi.org/10.1016/S1053-4822(97)90010-3

Brutus, S., Fleenor, J. W., \& London, M. (1998). Does 360-degree feedback work in different industries?: A between-industry comparison of the reliability and validity of multi-source performance ratings. Journal of Management Development, 17(3), $177-190$. https://doi.org/10.1108/EUM0000000004487

Chau, N., Gauchard, G. C., Siegfried, C., Benamghar, L., Dangelzer, J.-L., Français, M., ... Mur, J.-M. (2004). Relationships of job, age, and life conditions with the causes and severity of occupational injuries in construction workers. International Archives of Occupational and Environmental Health, 77(1), 60-66. https://doi.org/10.1007/s00420-003-0460-7

Du, L., Tang, W., Liu, C., Wang, S., Wang, T., Shen, W., ... Zhou, Y. (2016). Enhancing engineer-procure-construct project performance by partnering in international markets: Perspective from Chinese construction companies. International Journal of Project Management, 34(1), 30-43. https://doi.org/10.1016/j.jproman.2015.09.003

Eurostat. (2015). Accidents at work statistics-Statistics Explained. Retrieved from https://ec.europa.eu/eurostat/statisticsexplained/index.php/Accidents_at_work_statistics

Fadier, E., \& De la Garza, C. (2006). Safety design: Towards a new philosophy. Safety Science, 44(1), 55-73. https://doi.org/10.1016/j.ssci.2005.09.008

Floyd, I. I. H. L., \& Liggett, D. P. (2010). Hazard mitigation through design. IEEE Industry Applications Magazine, 16(3), 17-22.

Frijters, A. C. P., \& Swuste, P. H. J. J. (2008). Safety assessment in design and preparation phase. Safety Science, 46(2), $272-281$. https://doi.org/10.1016/j.ssci.2007.06.032

Gambatese, J. A. (2000). Safety in a designer's hands. Civil Engineering; New York, 70(6), 56-59.

Gambatese, J. A., Behm, M., \& Rajendran, S. (2008). Design's role in construction accident causality and prevention: Perspectives from an expert panel. Safety Science, 46(4), 675-691. https://doi.org/10.1016/j.ssci.2007.06.010

Gambatese, J. A., \& Hinze, J. (1999). Addressing construction worker safety in the design phase: Designing for construction worker safety. Automation in Construction, 8(6), 643-649. https://doi.org/10.1016/S0926-5805(98)00109-5

Gittleman, J. L., Gardner, P. C., Haile, E., Sampson, J. M., Cigularov, K. P., Ermann, E. D., ... Chen, P. Y. (2010). [Case Study] CityCenter and Cosmopolitan Construction Projects, Las Vegas, Nevada: Lessons learned from the use of multiple sources and mixed methods in a safety needs assessment. Journal of Safety Research, 41(3), 263-281. https://doi.org/10.1016/j.jsr.2010.04.004 
Hallowell, M. R., \& Gambatese, J. A. (2009). Activity-Based Safety Risk Quantification for Concrete Formwork Construction. Journal of Construction Engineering and Management, 135(10), 990-998. https://doi.org/10.1061/(ASCE)CO.1943-7862.0000071

Haslam, R. A., Hide, S. A., Gibb, A. G. F., Gyi, D. E., Pavitt, T., Atkinson, S., \& Duff, A. R. (2005). Contributing factors in construction accidents. Applied Ergonomics, 36(4), 401-415. https://doi.org/10.1016/j.apergo.2004.12.002

Hinton, P. R., McMurray, I., \& Brownlow, C. (2014). SPSS explained. Routledge.

Huang, X., \& Hinze, J. (2003). Analysis of Construction Worker Fall Accidents. Journal of Construction Engineering and Management, $129(3), 262-271$. https://doi.org/10.1061/(ASCE)0733-9364(2003)129:3(262)

ILO. (2013). Estadísticas del salud y seguridad. Retrieved 22 March 2019, from International Labor Organization website: https://www.ilo.org/global/statistics-and-databases/statistics-overview-and-topics/safety-and-health/lang--es/index.htm

IMF. (2018). Report for Selected Countries and Subjects. Retrieved 26 March 2019, from International Monetary Fund website: https://www.imf.org/external/pubs/ft/weo/2018/02/weodata/index.aspx

Ismail, Z., Doostdar, S., \& Harun, Z. (2012). Factors influencing the implementation of a safety management system for construction sites. Safety Science, 50(3), 418-423. https://doi.org/10.1016/j.ssci.2011.10.001

Likert, R. (1932). A technique for the measurement of attitudes. Archives of Psychology, 22, 140, 55.

London, M., \& Wohlers, A. J. (1991). Agreement Between Subordinate and Self-Ratings in Upward Feedback. Personnel Psychology, 44(2), 375-390. https://doi.org/10.1111/j.1744-6570.1991.tb00964.x

López-Arquillos, A., Rubio-Romero, J. C., \& Gibb, A. (2012). Analysis of construction accidents in Spain, 2003-2008. Journal of Safety Research, 43(5), 381-388. https://doi.org/10.1016/j.jsr.2012.07.005

Meliá, J. L., Mearns, K., Silva, S. A., \& Lima, M. L. (2008). Safety climate responses and the perceived risk of accidents in the construction industry. Safety Science, 46(6), 949-958. https://doi.org/10.1016/j.ssci.2007.11.004

Mills, F. T., \& Glass, J. (2009). The construction design manager's role in delivering sustainable buildings. Architectural Engineering and Design Management, 5(1-2), 75-90. https://doi.org/doi.org/10.3763/aedm.2009.0908

Morillas, R. M., Rubio-Romero, J. C., \& Fuertes, A. (2013). A comparative analysis of occupational health and safety risk prevention practices in Sweden and Spain. Journal of Safety Research, 47, 57-65. https://doi.org/10.1016/j.jsr.2013.08.005

Nunnally, J., \& Bernstein, I. (1994). Psychometric Theory. 3rd edition (MacGraw-Hill, New York).

OHSA. (2004). Prevention of risks in construction in practice (European Agency for Safety and Health at Work). Luxembourg: Office for Official Publications of the European Communities.

Recarte Suazo, G. A., \& Jaselskis. (1993). Comparison of Construction Safety Codes in United States and Honduras. Journal of Construction Engineering and Management, 119(3), 560-572. https://doi.org/10.1061/(ASCE)0733-9364(1993)119:3(560)

Salminen, S. (2004). Have young workers more injuries than older ones? An international literature review. Journal of Safety Research, 35(5), 513521. https://doi.org/10.1016/j.jsr.2004.08.005

Saurin, T. A., Formoso, C. T., \& Cambraia, F. B. (2008). An analysis of construction safety best practices from a cognitive systems engineering perspective. Safety Science, 46(8), 1169-1183. https://doi.org/10.1016/j.ssci.2007.07.007

Sawacha, E., Naoum, S., \& Fong, D. (1999). Factors affecting safety performance on construction sites. International Journal of Project Management, 17(5), 309-315. https://doi.org/10.1016/S0263-7863(98)00042-8

Spangenberg, S., Baarts, C., Dyreborg, J., Jensen, L., Kines, P., \& Mikkelsen, K. L. (2003). Factors contributing to the differences in work related injury rates between Danish and Swedish construction workers. Safety Science, 41(6), 517-530. https://doi.org/10.1016/S0925-7535(02)00007-3

Toole, T. M. (2005). Increasing Engineers' Role in Construction Safety: Opportunities and Barriers. Journal of Professional Issues in Engineering Education and Practice, 131(3), 199-207. https://doi.org/10.1061/(ASCE)1052-3928(2005)131:3(199)

Tymvios, N., \& Gambatese, J. A. (2016). Direction for Generating Interest for Design for Construction Worker Safety-A Delphi Study. Journal of Construction Engineering and Management, 142(8), 04016024. https://doi.org/10.1061/(ASCE)CO.1943-7862.0001134

Wang, W. C., Liu, J. J., \& Chou, S. C. (2006). Simulation-based safety evaluation model integrated with network schedule. Automation in Construction, 15(3), 341-354. https://doi.org/10.1016/j.autcon.2005.06.015

Zhao, D., McCoy, A. P., Kleiner, B. M., Mills, T. H., \& Lingard, H. (2016). Stakeholder perceptions of risk in construction. Safety Science, 82, 111-119. https://doi.org/10.1016/j.ssci.2015.09.002

Zhao, D., McCoy, A. P., Kleiner, B. M., Smith-Jackson, T. L., \& Liu, G. (2015). Sociotechnical systems of fatal electrical injuries in the construction industry. Journal of Construction Engineering and Management, 142(1). https://doi.org/10.1061/(ASCE)CO.1943-7862 .0001036

Zhao, X., Hwang, B.-G., \& Pheng Low, S. (2014). Enterprise risk management implementation in construction firms: An organizational change perspective. Management Decision, 52(5), 814-833. https://doi.org/doi.org/10.1108/MD-02-2014-0082

Zou, P. X., \& Zhang, G. (2009). Comparative Study on the Perception of Construction Safety Risks in China and Australia. Journal of Construction Engineering and Management, 135(7), 620-627. https://doi.org/10.1061/(ASCE)CO.1943-7862.0000019 